\title{
On spatiality in Tartu-Moscow cultural semiotics: The semiotic subject
}

\author{
Anti Randviir \\ Department of Semiotics, University of Tartu \\ Tiigi St. 78, 50410 Tartu, Estonia \\ e-mail: anti.randviir@ut.ee
}

\begin{abstract}
The article views the development of the Tartu-Moscow semiotic school from the analysis of texts to the study of spatial entities (semiosphere being most well known of them). It comes to light that 'culture' and 'space' have been such notions in Tartu-Moscow School to which, for instance, the 'semiosphere' does not add much. There are studied possibilities to join Uexküll's and Lotman's basic concepts (as certain grounds of Estonian semiotics) with Tartu-Moscow School's treatment of culture and space through the notion of 'semiotic subject'. Such an approach allows to see transdisciplinarity, which has come to issue only during the last decade, already in the first conceptions of Tartu-Moscow School where transdisciplinarity revealed itself in the symbiotic use of 'culture' and 'space'.
\end{abstract}

The Tartu-Moscow school of semiotics (TMS) has often been labelled as (the) one of cultural semiotics. Indeed, an article from the period until which semiotics had been dealt with in Tartu for nearly 10 years, appeared under the title Theses of Cultural Semiotics as the manifesto of the school (Uspenskij et al. 1973). This paper is definitely worthy of notice and a remarkable piece on bordering a paradigm in semiotics, which does not happen too often. On the other hand, if we look at further developments of the Tartu-Moscow thought in cultural semiotics, we can but conclude that neither 'semiotics' nor 'culture' were (or have been) understood as uniformly as to actually characterise a 'school' in a strict paradigmatic sense. There are five definitions of 'culture' and at least three (less implicit ones might be added) of 'semiotics' outlined in the Conceptual Dictionary of the Tartu-Moscow School (Levchenko, Salupere 1999), and this definitely does not look as a fact characterising a paradigm. 


\section{Anti Randviir}

Thus, one may wish to look for other features that would allow us to speak about a real school or paradigm of thought. There is no doubt that 'secondary modelling systems' can be taken as the centre of TMS; sometimes the 'semiotics' of TMS is equalised with the study of either natural language or language-based sign systems (Revzin 1971). It is probably the occasional rigidity of TMS in its definitions that has made it possible to argue against its standpoints and key concepts (e.g., Sebeok 1988); there is, however, no doubt in that this rigidity has been — seemingly paradoxically — connected with heuristic innovativeness. It is clear that considering culture-genetic sign systems either as secondary or tertiary does not make any difference in respect to TMS's studies or its pretty vague methodology ${ }^{1}$. On the other hand, Sebeok's argument on such a difference ought to be kept in mind, if aspects resulting from the analysis of Umwelt were involved in the study of the cultural sphere...

\section{From text to (textual) space}

There is another way to see and define the position of TMS. This may seem simplistic, but has definitely important consequences for both understanding TMS and using it in contemporary analysis of sociocultural phenomena. The topic under discussion is the one of juxtaposition or, more frequently, open contrasting of diverse phenomena, or - in advance - of dissimilar spheres, beginning from elementary binaries to the cultural level. Often, the inspection of sociocultural phenomena has been subjected to choice between the analysis of either processes or structures (see, e.g., Archer 1996). Semiotics, all the more TMS's cultural semiotics, has been associated with structuralism so repeatedly that it is not worthwhile to spend time and space on this in the current paper. We might, however, take TMS under inspection, and find out that while individual treatments have identified themselves with structuralist standpoints (e.g., Lotman 1970), the overall impression of TMS must be that of a synthesis of the functionalist (or processual) and structuralist approach. It seems clear that the structuralist approach favours the entailment of juxtaposing, at least it should not be surprising to meet the viewing of

Noting such vagueness in methods has no evaluative aspect here, but is due to the ad hoc nature of the development of TMS; see Randviir 2005. 
texts, cultural phenomena or the world, in the end, as based on oppositions. Application of binaries has been a major feature of structuralists, be them either representatives of TMS, the Greimasian tradition, or others. While we can meet Greimas' devotion to the Aristotelian logical square under the notion of the semiotic square (Greimas 1987: 66, 78), and the appliance of it to diverse types of texts, in TMS thinking in binaries has been simpler - at least on the surface. There, however, is a common feature, if not a red line, in both conventions: be them categories of the semiotic square or binaries, the formative entities are univocally certain semantic or semiotic fields (in the sense of formal logic). In the TMS tradition, we can observe the use at least the following descriptive frames formed on the basis of binaries: culture-nature; culture-another culture; culture-nonculture; text-non-text; the textual- the extratextual ${ }^{2}$; textual worldextratextual world; I-(s)he; the own - the alien; etc. Even though these categories have been set in oppositions, and they do encompass non-identical inner components, it is hard to find, in TMS works, any other treatment of their relations than those acknowledging dynamism (following, basically, the developmental pattern of centre-periphery). This, in short, means that the structural view is, in TMS, immanently conjoined with the functionalist/processual ideology.

Now, if we understand the constituents of the above-mentioned oppositions as dynamic structures (e.g. semantic fields, textual bodies, physical phenomena), we can, in brief, maintain that TMS has, to a large extent, been a school of the semiotics of space. Thinking in/about spheres has been customary in TMS, beginning from 'textual spaces' to individual's identity or, at the end, the semiosphere. There are several features or factors we can bring forward as evidence in TMS that concur with the semiotics of space, and most of those characteristics are of keynote importance for the identification of TMS itself. The 'text', as a central notion of TMS, has a certain inner

2 It is important here to pay attention to difference between the English 'extratextual' and the Russian 'vnetekstovyi'. Whereas 'extratextual' may or may not include contextual or co-textual connections, the Russian original seems rather to indicate at a sphere differentiated from the 'textual' by a disjunctive boundary. At the same time, however, there occur also hints at the extratextual world as that composed of 'other texts'. For example, misunderstanding texts can happen in connection with "[...] non-understanding the significant orientation of a text as a whole (or elements of its global structure) towards other texts or the extratextual [vnetekstovyi] world" (Levin 1981: 88). 
structure which is organised around or according to a certain dominant, the text is distinguished from the extratextual by a boundary... (Lotman 1969: 470f). The qualities of text can — and often have been - extrapolated to the level of culture, and thus, in the context of TMS, one would rather keep in mind the notion of cultural space. Cultural spaces are interpretable also from an internal viewpoint that takes into account communicative cohesion entailing a certain autocommunicative whole. From such an internal viewpoint, a basic criterion for the definition of a cultural space is the existence of self-explanatory self-models (or: 'automodels' — avtomodelj). Such self-models have, in TMS where autocommunication has always been highly valued, been explained and associated with textual terminology as follows - a self-model is:

A model of a given culture of itself which, as a rule, yields certain dominants in it on the basis of which there is built a unifying system that has to serve as a code for self-consciousness and self-identification of texts of the given culture. (Lotman 1971: 170)

An integrated cultural space, in turn, may be referred to as a textual conglomeration in which there goes on hermeneutic cultural movement where texts and metatexts exist in a dynamic cycle, where the cultural object-level and metalevel descriptions are interdependent. The so-called Petersburg text, for example, is "[...] one of the basic 'texts-interpreters' for the 'neomythological' works of the Russian symbolists" (Mints, Bezrodnyi, Danilevskij 1984: 80). At the same time, into the 'Petersburg text' there are included not only lexical texts, but also architectural, sculptural items (Mints, Bezrodnyi, Danilevskij 1984: 82). This means that semiotic and physical aspects of the city-space are joined in interaction.

On the other hand - space in text is:

[...] a modelling language by the help of which any meanings can be expressed as soon as they have the character of structural relations. Therefore spatial organisation is one of the universal means for the construction of any cultural models. (Lotman 1986: 4)

This opinion is one of those suggesting that the development of metalanguage(s) in TMS has most frequently been extremely closely connected with objects in their so-to-speak innocent status on the 
research table, before an actual analysis begins. As mentioned, 'texts' have often been replaced with 'textual spaces', 'cultures' with 'cultural spaces' already on the so-to-speak object-level in TMS (objects are defined with the preface of as even prior to analysis). Space, in this aspect, serves as a descriptor, and can be replaced by 'system', 'mechanism' (e.g., 'system of culture' as that of norms; cf., e.g., Zoljan, Černov 1978: 155, 162). This simplicity of replacing or loading objects of analysis with descriptive (or ideological, if you will) features prior to actual analysis has been admitted also by Lotman whose note can complement the above citation:

[...] space often obtains a metaphorical character by which metaphoricity is introduced into the language of investigative description. This is connected with that the notion of space itself contains a contradiction: it is filled with both mathematical and behavioural contents. This contradiction, in itself, may even play a supportive - creative - role, if it is recognised and purposefully used by the researcher. (Lotman 1986: 5)

Apparently, this understanding has made it easy for TMS to often talk about the above-mentioned textual spaces, whereas such textual spaces may extend to the field of describing behaviour, even lives of people, in textual terms. 'Behavioural texts' are, like any other cultural phenomena, built on natural language and belong, thus, to the realm of secondary modelling systems (see Lotman 1977: 66). Such phenomena are, in TMS's works, described in entirely textual terms dominant (or constants of behaviour), genre, sujet, style, etc. come to forth (Lotman 1977). The text is, in TMS, understood in broad terms and hints at phenomena created through secondary modelling systems based on natural language. Maybe surprisingly, such a logic draws attention to the proximity of TMS to any other discipline (e.g. cultural anthropology) studying cultural or sociocultural phenomena in merely other terminology. It stands in the theses of cultural semiotics that:

The fundamental concept of modern semiotics - the text - [...] has integral meaning and integral function [...]. In this sense it may be regarded as the primary element (basic unit) of culture. (Uspenskij et al. 1973: 6)

That 'culture' is mostly described in spatial terms (e.g. 'cultural sphere', opposition of the 'inside' and 'outside' of culture, culture as a 'delimited sphere', etc., etc.), text comes to share the spatial essence of culture, especially in the term 'cultural text' (or 'culture text'): 


\section{Anti Randviir}

In defining culture as a certain secondary language, we introduce the concept of a 'culture text', a text in this secondary language. (Uspenskij et al. 1973: 11)

'Cultural texts' can be compared to 'cultural phenomena' (or 'cultural units', even both semiotic and physical 'culture traits', etc.) in anthropology, and reinforce the impression of culture as a space of integrated structural (cultural texts) and functional (cultural languages) features. As it stands in TMS's theses:

The concept 'text' is used in a specifically semiotic sense and, on the one hand, is applied not only to messages in a natural language but also to any carrier of integral ("textual") meaning — to a ceremony, a work of the fine arts, or a piece of music. (Uspenskij et al. 1973: 6)

Keeping in mind the above-cited Lotman's opinion (Lotman 1986: 5), it therefore probably would not be wrong to suggest that the notions of text and space are mutually influential, if — in TMS - not even interdependent. This interdependence comes extremely vividly forth nowadays when modern technology itself forces to see and talk about the hypertextual space of global communication. Now, communication, the nature of space and the structure of texts are intertwined, and we talk about intertextual spaces, intersemiotic and intersemiosic communication. On the one hand, it may seem as if textual spaces have, by the development of modern technology (Internet, hyperspace, cyberspace, virtual space, in fact also cosmic space), lost one of their originally inherent feature - that of being bordered and structured thereby. On the other hand, these developments can also be seen in the light that those boundaries have been and are being transformed from the disjunctive into conjunctive ones. We can witness this transformation, or presupposition of such a transformation, already in the concept of the semiosphere (Lotman 1984, for a version in English see Lotman 1990). The semiosphere complicated the intertwined web containing 'text', 'space', 'culture', etc., with the idea of linguistic interaction and internal translatability (Lotman 1984: 11-16). In a way, one may thus compare the semiosphere to 'linguistic spaces' in a wider sense, but also to 'translation spaces' in a broader sense as well. 


\section{Semiotic space and semiotic subject}

The last nuance seems to have greater importance than only for the paradigm of cultural semiotics. Namely, here shows another possibility to see the proximity of cultural semiotics and (cultural) anthropology: 'culture bearers' as actual representatives of a socium can be understood in textual perspective. The conditional or analytic textuality of actual culture bearers provides them with a certain principle - or universal, if you will - features that enable us to apply a unified toolkit at the analysis of individual members of a socium. The actual physical nature of culture bearers as carriers of both physical an semiotic culture traits adds a most pragmatic dimension to the so-to-speak textualised individuals in a cultural space. At the same time, understanding cultures and/or societies in textual terms shares the same countenance: we may view these objects as cultural spaces in which holds a certain linguistic, semiotic, textual, translational congruity (cf. the semiosphere). Thus the individual and the collective-cultural level come to share (several) features, and from the semiotic perspective - we can apply a unified methodology to the micro- and macrolevel, treating our research objects as semiotic subjects. Semiotic subjects can be understood as semiotically bordered (semiotically distinct) and semiotically active physical organisms or conditionally distinct organisms. At the same time those distinct organisms must have a common share in order to be able to form sociocultural (or [inter-] textual) wholes connected through communication. That common share concerns knowledge of both rules and lexicon of semiosis; thus semiotic subjects can, again, be seen as internally cohesive informational spaces that exist in an interconnected (inter-) textual space. That common space presupposes also at least some differences in the stock of knowledge of its individual units - otherwise it would not be possible to talk about communication as exchange.

The notion of the semiotic subject is important for setting cultural semiotics in a wider perspective, and also in a larger semiotic context. Namely, it does not seem productive to approach semiosic activity as necessarily taking place between two ontologically separate subjects. When we talk about two semiotic spheres and their (partial) semiotic dissimilarities that create a situation of such semiotic tension that leads to the emergence of meaning, then there is no longer need to 
consider those semioactive subjects as separate also on the ontological plane. The emergence of meaning is made possible in a tension field which surfaces (in-) between two semiotic subjects, and involves diverse cases of the so-called unilateral communication, autocommunication, intracultural communication, etc. Thus the concept of the semiotic subject implies two main functions of semiosis. Semiosis is (a) a connector of meaningful units and structures in a way that enables communication between entities containing and/or using (those) meaningful phenomena (e.g. man). Or in other words semiosis is a creator of consistency by making it possible for different meaningful levels and units to get organised into a coherent functional structure. On account of such an integrating and so-to-speak subjectforming influence there also becomes possible semiosis as a part in (b) interaction between a semiotic subject and other subjects and the environment.

In semiotics, on the basis of approaching the object, sometimes a distinction is made between two fundamental trends - the semiotics of the sign and the semiotics of the code. Whereas it has been noted that "a semiotics of the code is an operational device in the service of a semiotics of sign production" (Eco 1976: 128), we probably should admit the fundamental interdependence of the two. According to the relevant processes, we can call them semiotics that studies either signification or communication. At the same time, one can easily share the opinion that no communication (between semiotic subjects) can be executed without signs. This means that the semiotics of the code (or: communication) cannot be developed without involving the study of signification. Likewise, no signification phenomenon can appear without at least two partakers (even though both can be generated by one and the same physical communicator), which makes it difficult for the semiotics of the sign to do without the level of the code and communication.

The two major fields of semiosic action - keeping a semiotic subject coherent, and interaction with the 'outside' — can be associated with two great concepts in semiotics that have to do with the relevant research traditions. These notions are J. von Uexküll's 'umwelt' and J. M. Lotman's 'semiosphere' that are keys for the biosemiotic and culturosemiotic perspectives. It should be kept in mind that we can really call them perspectives or accents, since both terms can be applied to the description of both natural and cultural 
phenomena; likewise are their historical backgrounds and essences similar. It is highly noteworthy that biosemiotics and cultural semiotics are fundamentally alike also methodologically: both favour the treatment of their objects in metaphorical manners. Interestingly, the two concepts mentioned are comparable historically and developmentally. In 1940, 'umwelt' has been defined as the self-centred world of an organism:

Each Umwelt forms a closed unit in itself, which is governed, in all its parts, by the meaning it has for the subject. According to its meaning for the animal, the stage on which it plays its life-roles (Lebensbühne) embraces a wider or narrower space. This space is built up by the animal's sense organs, upon whose powers of resolution will depend the size and number of its localities (Orte). (Uexküll 1982: 30)

Around the same time, V. Vernadsky developed his conception of the biosphere as one containing all living matter (his monograph The Biosphere was published in 1926), and coined 'noosphere' (the biosphere containing intellect) as the former's continuation (later, 'noosphere' was proliferated by T. de Chardin, cf. Chardin 1960). These two latter terms formed basis for the 'semiosphere' which is defined by J. Lotman as a 'semiotic continuum' that is "filled by semiotic compounds of different types and diverse levels of organisation" (Lotman 1984: 6); or: "the semiosphere is a semiotic space outside which the very existence of semiosis is impossible" (Lotman 1984: 7).

Thus the terminological grounds of umwelt and semiosphere are connected with the biological realm, their germs lay practically in the same scientific epoch, and they have become popular, reachable and widely utilised during the same period (the "discovery" of Uexküll's work in the 1980s and translation into English in 1982, the first publication of the semiosphere in 1984 and translation into English in 1990).

At this point, we can bind these two notions - umwelt and semiosphere - with the semiotic subject in a way as the former allows to describe relations between the semiotic subject and its environment. The latter makes it possible to deal with the analysis of semiosis intrasubjectively: treating culture as a textual macro-object, via the notion of semiosphere, we can describe the consistency or cohesive essence of a semiotic subject on the textual level (cf., e.g., 
Taborsky 1997), just as well as semiosic processes preceding the textual in the so-to-speak intrasubjective communication. It is vital to keep in mind the importance of autocommunication and that a semiotic subject may create its own semiosphere without being in interaction with other umwelten. Likewise, (sensory) communication between umwelten does not necessarily entail semiospherical aspects.

\section{From culture to semiosphere and back}

However, we also ought to consider certain problems connected with TMS's spatial conceptions, especially those related to the semiosphere. These issues come to light when we follow our designed pattern of associating umwelt with communication between the semiotic subject and 'external world', and semiosphere with keeping the semiotic subject cohesive. Above, we mentioned that being bordered is one of the most important features of the semiosphere (cf. Lotman 1984: 7-11). This, however, raises several problematic and contradictory issues. Namely, inasmuch as "[...] the notion of the semiosphere is connected with a certain semiotic uniformity and individuality" (Lotman 1984: 7), and "[...] both notions presuppose the semiosphere to be discriminated from the outer-semiotic or aliensemiotic space by a border" (Lotman 1984: 8), there emerges a question: how does this border come to existence, or does it emerge at all, or is it somehow made up, fabricated? Lotman's claims inevitably lead to issues of the origin of that border in terms of its emergence either on the object-level, or its generation on the metalevel. In other words, be the boundary stake at either at object- or metalevel, it can only be outlined by contrasting an 'intrasemiotic' world to an 'outersemiotic' world, and as far as the outer sphere be not semiotised, possibilities of differentiation are but disregarded. Thus the 'absolute border' simultaneously presumes and dismisses possibilities of describing a semiosphere, and makes the depiction of this border - as the semiosphere in toto - possible from a shifted (e.g. divine or extraterrestrial) viewpoint that would enable to engage comparison of the internal and extra-semiospherical units. The original concept of the semiosphere is thus connected with understanding a semiotic reality of a community in totalitarian terms. It seems important to note that a totalitarian understanding of the semiosphere is, for Lotman, not an 
occasional affair - after two years of publishing the conception of the semiosphere, he maintains that the term refers to: "[...] the semiotic space of culture in which solely are possible semiotic processes" (Lotman 1986: 6). While, for Lotman, "[...] the 'closure' of the semiosphere lies in its inability to get involved with alien-semiotic texts or non-texts" (Lotman 1984: 8), then, in the current context, by the individuality of the semiotic subject, we understand the possibility to describe the semiotic reality as a cohesive, i.e. at least minimally individual whole. In actual case studies, from an internal viewpoint of a semiotic realm, the description of a meaningful world can be executed exactly against a background system which is often formed of 'non-cultural' or 'non-textual'. In order to specify the identity discourse of a semiotic subject, i.e. its (semiotic) boundaries, we must outline those borders somehow, and this can only be done by contrasting the outside of a semiotic reality with its interior. Here we are confronted with a paradoxical situation: in order to be able to talk about the semiotic subject and its individuality as a phenomenon based on contrast between the semiotised and non-semiotised world, and the dynamic border between them, we may conclude — this border is indefinable. More exactly, this boundary - thus likewise features resulting in the extent of the semiotic reality - cannot be circumscribed as persistent. This goes both for the semiotic metalevel, and all the more for the (hypothetically referred) semiotic reality on the object level: talking about the expanse of the meaningful world, we must - in order to describe its boundary - have semiotised elements of the (originally) 'meaningless world'. Evidently, thereby the latter elements are switched into the frame of the semiotic reality. With the intention of referring to the 'alien semiotic space' as a phenomenon outside the semiosphere, we must already have had it semiotised. Consequently, we should not equalise 'outside of semiotics' with 'alien semiotics', since the former cannot, in principle, be switched into (articulate) discourse. Therefore, when entities of a nonsemiotised world are, through semiosis, incorporated into a textual output, they can be referred to as representing 'non-culture', 'aliensemiotic', 'non-textual', rather than a sphere 'outside semiotic(s)'.

While, in connection with the creation of meaningfulness, there appear so many ambiguities at the definition of the semiotic subject and reality already due to the notion of the semiosphere, we probably should look for a more concrete phenomenon or a category through 
which to delimit the semiotic subject. Proceeding from the abovementioned possibilities to distinguish between reality and the semiotic reality, we may face the verity that, by default, our topic ought to be concerned with the unreadable/incomprehensible/scarcely interpretable on the one hand, and readable/understandable/interpretable on the other. This involves the factor of viewpoint and deprives us from the too categorical nature of J. Lotman's notion of the semiosphere. In fact, the heuristic value of the semiosphere can be cast to doubt, when we recall of those points in the theses of TMS that explain its views on the concept of culture. ${ }^{3}$ While Lotman's treatment of the semiosphere puts TMS's conception of culture often merely into another vocabulary, it seems that the original understanding can be more flexible and suitable for actual analysis:

In investigations of a semiotic-typological nature the concept of culture is perceived as fundamental. In doing so we should distinguish between the conception of culture from its own point of view and from the point of view of a scientific metasystem [...]. According to the first position, culture will have the appearance of a certain delimited sphere which is opposed to the phenomena [...] outside it. Thus the concept of culture is inseparably linked with the opposition of its 'non-culture'. (Uspenskij et al. 1973: 1)

It is important that TMS's original 'culture' is far less categorical than the 'semiosphere' in ten years after the Theses:

The sphere of extracultural nonorganization may sometimes be constructed as a mirror reflection of the sphere of culture or else as a space which, from the position of an observer immersed in the given culture, appears as unorganised, but which from an outer position proves to be a sphere of different organization. (Uspenskij et al. 1973: 3)

The application of textual approach to cultural phenomena seems to imply that semiotic structures, or semiotic subjects, can but be set in such an environment which is demarcated from such 'different organisations' in the manner as 'culture' is opposed to its outside. The combination of textualist and spatial vocabulary does not entail as categorical oppositions as contained in Lotman's treatment of the

3 We can but hypothesise the value of some ideas introduced by Lotman under the notion of the semiosphere, if the latter were replaced with 'the universe of the mind' as a scientific concept, not merely a title of Lotman's book in English (see Lotman 1990). 
semiosphere. We can meet evidence to this even in Lotman's own practical analysis of the so-called behavioural texts that are based on the dynamism between 'normal' and 'abnormal', 'normal' and 'artistic' spheres of behavioural modalities. Behavioural texts concern interaction between the cultural space both in the physical and purely semiotic sense; for example:

The Russia before Peter knew binary contrasting of the ritual and extraritual (non-ritual: vneritualjnoe) space in the world and in the space of human settlement. (Lotman 1977: 77)

It seems that considering TMS as a semiotic school centred around space has several important clues for understanding its development, just as well as significant consequences for scientific history. Space is one of the most basic and substantial categories for reflection and analysis; space is an object of study that can — and has been used by TMS - as a metalinguistic construction. This means that all through its history, TMS has been - already since the very beginnings in the 1960s — one of the few true transdisciplinary schools not only in humanities, but touching also the sphere of the so-called hard science (for instance in its reflections on cerebral/cultural dynamism; Chernigovskaya, Balonov, Deglin 1983; Nikolaechko, Deglin 1984). TMS started off as a discipline studying Russian literature; it ended up by viewing diverse cultural phenomena as cultural texts. It is important what this development brought along in its course, for this is probably one of the first cases of transdisciplinarity in the modern era after the (politically and militarily forced) slow death of the movement towards the Unified Science in the beginning of the 20th century. TMS began by studying texts of Russian literature, conditionally ending up by studying cultures as 'texts' or composed of a set of 'texts'. This seemingly minor shift in scientific approach has enormous, almost extraordinary significance in terms of a metalevel shift in general, and this may be one of the few unique cases of such metaphorical approaches that does have heuristic value. At the same time, the progress of TMS from analysing texts of Russian literature to analysing cultural phenomena in textual terms represents, as mentioned, probably one of the first contemporary transdisciplinary developments. TMS's employment of 'cultural text' was, in itself, a remarkably ingenious device (let us remind of Russian Formalism). This brought TMS considerably closer to other trends studying culture 
even by enabling, at the analysis of both physical and semiotic culture traits (let us remind of Ruth Benedict), to apply uniform methods, and to grasp the holism of physical and semiotic components of culture (let us remind of the Estonian folklorist Jakob Hurt and his oldhoard ${ }^{4}$ ). Culture as culture text is formed of such cultural texts the developmental logic of which should principally be hermeneutic; therefore the whole and its components are analysable by uniform methods. Such a state brings TMS closer, backwards, not only to the more dynamic side of Russian Formalism, but also with, for example, New Criticism (let us remind of T. S. Eliot). Likewise, obvious connections can be seen with the more rational part of those who dwelled on the Death of the Author ${ }^{5}$.

The positioning of cultural phenomena into sociocultural contexts allows talking about semiotic spaces and semiosis in diverse aspects of both perception and cognition. Thus, transdisciplinarity, in a sense, lies in objects, and the conglomeration of multiple perspectives and viewpoints draws attention to the futility of trying to separate 'methods' and 'disciplines' that has been an unfortunate topic in connection with semiotics in general. Viewing TMS as a school centred at the study and metalinguistic use of space, thus helps to see its connections with other traditions of thought and research; unfortunately there are but a few examples of suchlike studies yet (cf. e.g. Portis-Winner 1999). Transdisciplinarity is, in fact, not too implicitly implied by TMS itself already in its theses:

[...] together with an approach which permits us to construct a series of relatively autonomous sciences of the semiotic cycle, we shall also admit another approach, according to which all of them examine particular aspects of the semiotics of culture, of the study of the functional correlation of different sign systems. (Uspenskij et al. 1973: 1)

\footnotetext{
4 In Estonian: vanavara.

5 In principle, TMS turned the text into a spatial cultural phenomenon in both ontological and epistemic plane. Therefore we can probably make a short evaluation, maintaining that TMS's text's heuristic potential has, until now, overcome the one of space, but this is a topic worthy a longer individual treatment.
} 


\section{Construction of semiotic subjects}

Spatial thinking led us to the notion of the semiotic subject, the latter in turn, to problems connected with the partial rigidity of the conception of the semiosphere. It may even be considered dangerous to view the semiosphere - like J. Lotman did - as separated from the 'alien semiotic', because this would lead to the isolation of semiotic subjects. All the more, viewing macro-level semiotic subjects, e.g. nations, as operating in isolated semiospheres, points at direct peril realised in the course of history continuously. While in practical analysis it may turn out that semiotic subjects sometimes see their semiotic reality, or their particular semiosphere, as central and even singular (e.g. the exclusion of barbarians, the Nazi propaganda for the Arian race, civilised world vs. the Axis of Evil, etc.), this should not be regarded as a possibility on the metalevel. Selfpositioning in an exclusive manner has often been the case when aggressors have justified their military campaigns; it is exactly the 'civilised enclave' that has been stated as in need to 'cultivate' the outside, to find new living space for itself, or the similar. However, opposing the cultivated oikumene to the rest of the environment or the world is seldom the case at trials of defining such semiotic subjects as nations, for example. In a way, nation-formation is as different from the founding of a state or a related governmental structure as the latter are from the non-governmental. It is significant that contrary to prior cases in history, the foundation of nation-states in Europe centred on self-definition through the description of national sociocultural cores that were not necessarily opposed to others in the disjunctive modality. In a way, although nation-states appealed for a territory, their semiotic essence seems similar to contemporary nongovernmental organisations that are major agents in the process of globalisation. Such organisations are not rigid, although their cores tend to be stabile; their boundaries are rather lines of interaction, not those separating the 'own' from the 'alien semiotic'. Of course, the core-centred and inclusive semiotic subjects that may often not even have territorial claims, can be of diverse nature and goals (e.g., profit corporations vs. ideological organisations). Sometimes such organisations, however, can follow the ideology of making a distinction between the oikumenical and the 'alien semiotic' (e.g., terrorist organisations), but this is exactly the crucially grave situation we drew 
attention to in the above discussion. As mentioned, the (semio-) spherical or spatial conceptualisation of semiotic subjects is directly connected with the topic of identity (or: semiotic boundaries) and (self-) positioning in communication, be interaction concerned either with the interpersonal or intercultural level.

Today, intercultural communication first implies the question: what or who are its agents? Are we considering cultures, societies, races, states, nations, individuals or other possible subjects? Having picked one of them, it is further necessary to define what exactly is kept in mind. For example, if choosing 'cultures' to be the agents under inspection, we can probably rule out 'intercultural communication proper' because of the mass communication facilities unifying knowledge and behavioural patterns in the world. Today's world culture and the speed and extent of communication equalizes what used to be understood as distinct cultures, even culture areas, according to cultural anthropology (e.g., Kluckhohn 1961). Communication, literally as a technique of sharing, has homogenized knowledge, behaviour, available and usable communication channels and patterns among peoples inhabiting geographically incongruent and distant areas. Therefore it is difficult to demarcate distinct culture areas in the sense they were outlined only some decades ago. Today we can probably talk just about world culture forming a background system for human population varying in what is actualised in individual communities. Peoples operating with different languages, state organizations, or who are anthropologically (in the biological aspect) dissimilar, do not diverge much in terms of culture. Of course, we must remember that globalisation both homogenises sociocultural groups, and creates heterogeneity at the same time. If contemporary technical facilities are unavailable, so is knowledge channelled in them, and there emerge oases of informational lag or insufficiency.

How, then, to define a community? What forms its basis and influences the distinctive features distinguishing it from 'others'? Inasmuch as people nowadays have to define/relate themselves on the social level by belonging to a certain political structure, most commonly a state as a spatial structure, we are to involve topics surrounding the notion of 'nation' as major factors at the formation of contemporary European structure on the level of societies. It is interesting that while TMS frequently treats semiotic systems as operating within a social formation (in a 'socium', most often), it is 
difficult to find any concrete treatment or definition of the respective conglomeration itself. Instead of finding distinctness in understanding the 'society', 'collective' or the similar, the closest more or less demarcated notion is the 'nation'. Characteristically to TMS, this term lacks a clear-cut short definition (additionally has 'nation' sometimes been typologically compared to 'quasi-nation'), but we can pay attention to the following:

Definition 3. Basis: the city is a quasi-nation.

Let a collective of people $\mathrm{X}$ be defined, through the previous inductive step, as a quasi-nation, and let a collective of people $\mathrm{Y}$ share the conditions $1-4$, possibly also the 5th:

1) the territory of $\mathrm{X}$ borders or intersects with the territory of $\mathrm{Y}$;

2) $X$ and $Y$ use a common language;

3) $X$ and $Y$ are characterised by the unity of economic life;

4) $X$ and $Y$ have a common culture;

5) $\mathrm{X}$ is connected with $\mathrm{Y}$ by religious unity, mythological-epical unity of tradition, or unity of historical fate - then the union of $\mathrm{X}$ and $\mathrm{Y}$ is a quasination, its linguistic, cultural and other features are induced by the inductive step shaping it. [...] Every time the fulfilment of at least four features of five is required.

[...] Definition 5. [...] A quasi-nation is a nation, if [...] it opposes itself to neighbouring collectives through characteristic features and is conscious of itself as a coherent, closed commune. (Revzin 1977: 40)

This quotation shows, on the one hand, that 'nation' can be defined through subjective categories that, in fact, have been constructed and cannot be objectively verified. Even if, at first sight, language, territory or economic life may seem as definite distinctive features, they fade in terms of concrete reference proper, when we think of globalisation, the phenomenon of Diaspora, immigration and the diverse processes and levels of integration and assimilation. Territorial borders, orthographically correct language, the extent of self-sufficient economy are negotiated types of phenomena, not to talk about the relativity of cultural or religious belonging. The inherent essence of the named distinctive features as being constructed is evident and it is not worth to pay further attention to this trivialism here for longer. However, on the other hand, accepting their subjectivity, these categories start to function in the framework of a paradigm centred at 'semiotic space', 'semiosphere', 'chronotope', or 'semiotic subject' in our context. Revzin's stress on the importance of nation (as a semiotic subject) contrasted or opposed to 'others' connects TMS's discourse 


\section{Anti Randviir}

on the topic with the Western one in terms of approaching the phenomenon of nationalism. Additionally, the semiotic and spatial distinctive features essential for the definition of (nation as) a semiotic subject, allow us to see several parallels in describing sociocultural units in TMS and several Western schools of thought.

Nationalism is something that has often been mixed up with ethnicity, race, racism, etc. We must not waste time on topics similar to racism or the like, since it has been long proved that there truly exist dissimilar races on Earth, differing in reality probably only by some morphic features. The problem rather lies in how is it possible for bio-anthropologically alike subjects to differentiate their identity as strongly as to use severe violence in order to define and maintain themselves. In Europe nationalism has been a front cover negative issue mostly after WW2. Similarly, definitions of nationalism we can use belong to the same period. This is strange, because the idea of nation-specific entities dates back to the formation of the current European states. In short: at times of Enlightenment there was to be found an alternative to understanding social relations as based on (unequal) classes in favour of an 'equal' foundation for human relations. If in the case of e.g. an ethnos we can define the unit at least in linguistic and anthropological terms, defining a nation is much more problemsome. There are and have been used very many criteria to define nation (language, culture, territory, time, history, social structure, bio-anthropological peculiarities) of which the majority are negotiated, arbitrary and most conditional constructions. While it is quite common to meet condemning attitude to nationalism in the 'adequately polite' or 'politically correct' behaviour, e.g. in political statements, public discourse, etc., this cannot be the case in scholarship. Besides not being positive or negative, another issue is keeping in mind the difference between nationalism on the one hand, and chauvinism, patriotism and so forth on the other. Nationalism hints at the sentiment holding a community together and a rough rule of the need for congruence of an ethnic, linguistic, territorial and other dimensions mentioned above. Chauvinism, on the other hand, already refers to taking role in intercultural communication according to the principle of (high) self-evaluation. Revzin's understanding of the nation (except his fifth point of definition) suits the definition of the semiotic subject in the line of the so-to-speak positive nationalism, chauvinist nationalism can rather be described through the strict 
conception of the semiosphere. In actual research, the notion of positive nationalism allows us to apply TMS's conceptions of culture and text to macrolevel semiotic subjects, and thereby also textual and spatial dimensions and features come together.

\section{TMS: through space towards transdisciplinarity}

The appearance of TMS should not be regarded as out of the blue. Hypothetically, developmental stages of metacultures can be outlined as follows: discipline ${ }_{1} \rightarrow$ multidisciplinary studies $\rightarrow$ interdisciplinary studies $\rightarrow$ transdisciplinary studies $\rightarrow$ discipline $_{2} /$ new base discipline. This range can probably be altered in several ways (e.g. adding polydisciplinarity), but it seems that the development of TMS can be characterised according to this logic. Apparently, TMS's roots lay in the study of Russian literature, and literary history was and is a field of study considered as a discipline even nowadays. However, a semiotic attitude cannot but remain unsatisfied with the study of mere texts: this follows even from the logic that took the Chomskyan 'linguistic competence' to 'communicative', 'cultural', and 'semiotic competence'. In order to understand texts, one has to pay attention to the cultural contexts that influence comprehension of ways of solving communicative situations. Orientation in cultural realms demands also abilities to navigate in the semiotic reality in terms of comprehending and distinguishing between concrete and abstract referents. By way of enlarging contexts (in addition to the literary, also cultural, social, economical, etc.), TMS managed to expand the study of texts to all of the named spheres of cognitive competences.

The linguistic perspective and analysis of strictly literary texts was replaced by the study of cultural phenomena (including literary texts). The latter were (multi-) contextually positioned, and that enabled TMS to widely use spatial terms in concrete analysis of literary texts. Space in text and textual spaces as objects and research trends indicate that first space was, in a way, quite strictly the space of a secondary modelling system (e.g. that of literature). Cunningly, in such a way space gradually became into the actual object of study (sometimes called also as [sociocultural] chronotopes), while relatedly, spatial terms obtained higher and higher importance also for the metalanguage (from 'textual space' to e.g. 'city space', 'semiosphere' in 


\section{Anti Randviir}

the end). Besides texts as output of secondary modelling systems, it was realised that there exist also physical and historical contexts of text-generation, and these implied the recognition of diverse spatial levels:

At the same time, while the spatial language interests us not from the viewpoint of its genesis, but as the modelling code of culture, we must study its complexity and understand that in reality the position is held not by a certain single language, but a hierarchy of spatial languages. (Lotman 1986: 6)

This is probably a background for the relatively high popularity of TMS and the applicability of its metalinguistic constructions to quite diverse phenomena - in fact, cultural semiotics along with its object of study, the semiotic space, can be considered as one of the first instances of transdisciplinarity as mentioned above. TMS, having its start-off in Russian literature studies as a discipline, passed through the above mentioned stages of development, became into an individual discipline, and - having reached the level of transdisciplinarity - can now be considered as a methodological basis on which to build the study of sociocultural phenomena in general. The use of TMS's toolkit for the description of culture along with its spatio-semiotic terminology could be a unified perspective to analyse sociocultural phenomena and semiotic subjects in contemporary situation of globalisation. When we keep ourselves conscious to employ the conception of the semiosphere only in the manner as neglecting its certain above-described totalitarian insinuations and remind of its roots in TMS's original understanding of culture (which seems much more functional than the concept of semiosphere), and enhance such a view on semiotic subjects with implements coming from the model of the umwelt, we may find ourselves at a transdisciplinary threshold proper. ${ }^{6}$

\footnotetext{
Research for this article has been supported by Estonian Science Foundation grant 6729 .
} 


\section{References}

Archer, Margaret Scotford 1996 [1988]. Culture and Agency: The Place of Culture in Social Theory. Revised edition. Cambridge: Cambridge University Press.

Chardin, Pierre Teilhard de 1960. The Phenomenon of Man. London: Collins.

Chernigovskaya, T. V.; Balonov, L.; Deglin, V. L. 1983 = Черниговская, T. В.; Балонов, Л. Я.; Деглин, В. Л. 1983. Билингвизм и функциональная асимметрия мозга. Tpyды по знаковым системам (Sign Systems Studies) 16: $62-83$.

Eco, Umberto 1976. A Theory of Semiotics. (Advances in Semiotics.) Bloomington: Indiana University Press.

Greimas, Algirdas J. 1987. On Meaning: Selected Writings in Semiotic Theory. (Theory and History of Literature, 38.) Minneapolis: University of Minnesota Press.

Kluckhohn, Clyde 1961. Mirror for Man: A Survey of Human Behavior and Social Attitudes. Greenwich: Fawcett.

Levchenko, Jan; Salupere, Silvi (eds.) 1999. Conceptual Dictionary of the TartuMoscow Semiotic School. (Tartu Semiotics Library 2.) Tartu: Tartu University Press.

Levin, Juri 1981 = Левин, Юрий И. Тезисы к проблеме непонимания текста. Труды по знаковым системам (Sign Systems Studies) 12: 83-96.

Lotman, Juri 1969 = Лотман, Юрий М. 1969. О метаязыке типологических описаний культуры. Труды по знаковым системам (Sign Systems Studies) 4: $460-477$.

- 1970 = Лотман, Юрий М. Структура художественного текста. Москва: Искусство.

- 1971 = Лотман, Юрий М. Проблема “обучения культуре” как её типологическая характеристика. Tруды по знаковым системам (Sign Systems Studies) 5: 167-176.

- 1977 = Лотман, Юрий М. Поэтика бытового поведения в русской культуре XVIII века. Tруды по знаковым системам (Sign Systems Studies) 8: 65-89.

- 1984 = Лотман, Юрий М. О семиосфере. Труды по знаковым системам (Sign Systems Studies) 17: 5-23. [In English: Lotman, Juri 2005. On the semiosphere. Sign Systems Studies 33(1): 205-229.]

- 1986 = Лотман, Юрий М. От редакции: К проблеме пространственной семиотики. Труды по знаковым системам (Sign Systems Studies) 19: 3-6.

- 1990. Universe of the Mind: A Semiotic Theory of Culture. (Shukman, Ann, trans.; Eco, Umberto, introduction.) London, New York: I. B. Tauris \& Co Ltd.

Mints, Zara G.; Bezrodnyi, M. V.; Danilevskij, А. А. 1984 = Минц, 3. Г.; Безродный, М. В.; Данилевский, А. А. 1984. "Петербургский текст" и русский символизм. Tруды по знаковым системам (Sign Systems Studies) 18: 78-92. 


\section{Anti Randviir}

Nikolaechko, N. N.; Deglin, V. L. 1984 = Николаечко, Н. Н.; Деглин, В. Л. Семиотика пространства и функциональная асимметрия мозга. Tpуды по знаковым системам (Sign Systems Studies) 17: 48-67.

Portis-Winner, Irene 1999. The dynamics of semiotics of culture: Its pertinence to anthropology. Sign Systems Studies 27: 24-45.

Randviir, Anti 2005. Cultural Semiotics and Social Meaning. In: Bankov, Kristian (ed.), Culture and Text, vol. X EFSS'2004. Sofia: New Bulgarian University Press, 114-128.

Revzin, Isaak 1971 = Ревзин, Исаак И. Субъективная позиция исследователя в семиотике. Труды по знаковым системам (Sign Systems Studies) 5: 334-344.

- 1977 = Ревзин, Исаак И. 1977. Об индуктивных определениях в исторических науках (к логической экспликации понятий “нация” и “национальный язык”). Tpyды по знаковым системам (Sign Systems Studies) 8: $28-44$.

Sebeok, Thomas A. 1988. In what sense is language a "primary modeling system?" In: Broms, Henri; Kaufmann, Rebecca (eds.), Semiotics of Culture. Helsinki: Arator, 67-80.

Taborsky, Edwina 1997. The Textual Society. (Toronto Studies in Semiotics.) Toronto, Buffalo, London: University of Toronto Press.

Uexküll, Jakob von 1982. The theory of meaning. Semiotica 42(1): 25-82.

Uspenskij, Boris A., et al. 1973. Theses on the semiotic study of cultures (as applied to Slavic texts). In: van der Eng, Jan; Grygar, Mojmír (eds.), Structure of Texts and Semiotics of Culture. The Hague, Paris: Mouton, 1-28.

Vernadsky, Vladimir 1989 = Вернадский, Владимир И. Биосфера и ноосфера. Москва: Наука.

Zoljan, Suren T.; Černov, Igor A. 1977 = Золян, Сурен Т.; Чернов, Игорь А. О структуре языка описания поведения. Труды по знаковым системам (Sign Systems Studies) 8: 151-163.

\section{О пространственности в семиотике культуры Тартуско- Московской школы: семиотический субъект}

В статье рассматривается развитие ТМШ от анализа текста до изучения пространственных семиотических единиц (из них наиболее известная - семиосфера). В то же время предпринимается попытка показать, что в семиотике ТМШ такие понятия, как например, «культура» и «пространство», не нуждаются в прибавлении термина «семиосферы». В статье изучаются возможности связать базовые понятия Юкскюлля и Лотмана (как основы эстонской семиотики) с описанием культуры и пространства в ТМШ посредством «семиотического субъекта». Такой подход позволяет увидеть трансдисциплинарность уже в начальных разработках ТМШ, где симбиотически использовались «культура» и «пространство». 


\title{
Ruumilisusest Tartu-Moskva kultuurisemiootikas: Semiootiline subjekt
}

\begin{abstract}
Artiklis vaadeldakse Tartu-Moskva semiootikakoolkonna arengut tekstianalüüsist ruumiliste semiootiliste üksuste uurimiseni (viimastest tuntuim on semiosfäär). Samas püütakse näidata, et Tartu-Moskva semiootikas on olnud nt 'kultuuri' ja 'ruumi' näol tegemist selliste mõistetega, millele nt 'semiosfäär' juurde ei panusta. Uuritakse võimalusi ühendada Uexkülli ja Lotmani baasmõisted (Eesti semiootika alustaladena) Tartu-Moskva koolkonna kultuuri- ja ruumikäsiteluga 'semiootilise subjekti' kaudu. Seesugune lähenemine võimaldab näha alles viimasel kümnendil tähtsustunud transdistsiplinaarsust juba Tartu-Moskva algkontseptsioonides, mis avaldusid 'kultuuri' ja 'ruumi' sümbiootilises kasutamises.
\end{abstract}


